\title{
Observational study of maternal anthropometry and fetal insulin
}

\author{
H Soltani-K, C Bruce, R B Fraser
}

\begin{abstract}
Aims-To examine the relation between maternal body fat and fetal metabolism. Methods-In this observational study, cord blood samples were collected from 60 infants of healthy women for the measurement of insulin and $C$ peptide concentrations. Maternal weight, height, body mass index (BMI) and body composition (skinfold thickness measurements and bioelectrical impedance) were assessed at 13-15 weeks of gestation. Twenty five of the volunteers agreed to have a $75 \mathrm{~g}$ oral glucose tolerance test at 28-31 weeks of gestation.
\end{abstract}

Results-Positive correlations were observed with both cord insulin or $\mathrm{C}$ peptide concentrations and maternal early pregnancy $B M I(r=0.44, p=0.002$ and $r=0.33$, $\mathrm{p}=0.008$, respectively). There was no significant correlation between cord insulin or $\mathrm{C}$ peptide concentrations and birthweight or birth weight centiles.

Conclusion-Maternal BMI could be a predictor of fetal cord insulin concentration.

(Arch Dis Child Fetal Neonatal Ed 1999;81:F122-F124)

Keywords: maternal anthropometry; body composition; insulin; body mass index

Insulin and related peptides are major anabolic factors in the regulation of intrauterine growth. Increased deposition of adipose tissue and enhanced lean body mass have been observed in hyperinsulinaemic infants born to diabetic mothers. These findings have also been confirmed in experimental studies on animals with induced hyperinsulinaemia. ${ }^{1}$

On the other hand, the risk of macrosomia (defined as birthweight $>4000 \mathrm{~g}$ ) was higher among the infants born to non-diabetic obese mothers ${ }^{2}$ than among the non-obese ones. Obese gravid women have a higher incidence of fasting hyperglycaemia and increased insulin resistance. ${ }^{3}{ }^{4}$ In a study by Langhoff-Roos et $a l{ }^{5}$ maternal fat mass at 37 weeks was associated with maternal basal insulin concentration. There is little information on the relation between maternal BMI (as a convenient measure of maternal obesity) and fetal insulin concentrations.

\section{Methods}

Sixty caucasian women were recruited at the antenatal booking clinics of the Northern General Hospital, Sheffield. All of them were healthy, normotensive, and non-diabetic with singleton pregnancies. Maternal weight (using a Seca 760 scale, Cranlea, Birmingham), height and body composition (using bioelectrical impedance analyser (BIA) and skinfold thickness measurement (STM)) were measured in early pregnancy (13-15 weeks). Maternal body mass index (BMI) was calculated as maternal weight/height ${ }^{2}\left(\mathrm{~kg} / \mathrm{m}^{2}\right)$.

A four electrode bioelectrical impedance analyser (BIA, E-Z 1500, Cranlea, UK) is a convenient method of measuring body composition. This method has been used to assess body composition in pregnant women, with no reports or evidence of any harm to the mother or to the fetus. ${ }^{67}$ During measurements, the women wore clothes but no footwear, and were supine on a couch. Measurements were taken on the left side of the body. After cleaning with alcohol and drying all skin contact areas, arginine foil spot electrodes were placed on the dorsal surfaces of the hands and feet at the distal metacarpals and metatarsals, respectively, and also medially between the distal prominences of the radius and the ulna and between the medial and lateral malleoli at the ankle. A small electric current was run through the volunteer and the voltage drop was detected with the proximal electrodes. Fat is a poor conductor of applied current; lean tissue comprising water and electrolytes is highly conductive. Total body water was therefore measured and lean mass (LM) estimated from this, by assuming that a certain proportion of this tissue is water. Body fat mass (FM) can then be determined by subtracting the estimate of lean mass from the total weight.

Maternal fat mass was also estimated using skinfold thickness measurements (Holtain callipers, Holtain LTD, Crymych, UK). ${ }^{8}$ Skinfold thickness was measured by pinching a fold of skin with associated subcutaneous fat between the jaws of Holtain callipers at the predetermined sites (triceps, biceps, subscapular and supra-iliac). The sum of the skinfolds was converted to an estimate of body density, using the formula developed by Durnin and Womersley. ${ }^{9}$ Siri's equation ${ }^{10}$ was then used to estimate fat mass.

Cord vein blood samples were collected at delivery from the neonates (gestational age: 38-41 weeks). The samples were centrifuged, the plasma separated and stored at $-20^{\circ} \mathrm{C}$ before assay.

Twenty five of the volunteers agreed to a 75 g oral glucose tolerance test at 28-31 weeks of gestation. Plasma glucose was assessed using a glucose oxidase method with a glucose analyser (Yellow Springs Instrument [YSI], Model 23 AM, Clandon Distributor, UK). Plasma insulin was measured using an in-house double 
Table 1 Characteristics of the subjects $(n=60)$ studied

\begin{tabular}{ll}
\hline & Mean $(S D)$ \\
\hline Early pregnancy weight $(\mathrm{kg})$ & $72.1(18.0)$ \\
Height $(\mathrm{m})$ & $1.6(0.1)$ \\
Body mass index $\left(\mathrm{kg} / \mathrm{m}^{2}\right)$ & $27.2(6.4)$ \\
Parity & $0.8(0.7)$ \\
Fat mass $(\mathrm{kg})$ & $24.3(10.9)$ \\
Fat mass $(\mathrm{kg})$ & $26.5(12.6)$ \\
Length of gestation (weeks) & $39.3(1.3)$ \\
Infant birthweight $(\mathrm{g})$ & $3518.0(480.0)$ \\
Placental weight $(\mathrm{g})$ & $622.0(119.0)$ \\
\hline *As measured by skinfold measurements; $†$ As measured by
\end{tabular}

bioelectrical impedance.

antibody radioimmunoassay technique. Guildhay's RIA kit (Guildhay Ltd, Guildford, Surrey, UK) was used for the determination of $\mathrm{C}$ peptide concentrations. The interassay and intra-assay coefficients of variation were $7.4 \%$ and $6.8 \%$ for insulin, $8.5 \%$ and $6.4 \%$ for C peptide, respectively. Haemolysis to any degree can affect the accuracy of the insulin assay but not the $\mathrm{C}$ peptide concentration. ${ }^{11}$ Therefore, C peptide was measured in all the samples, but insulin concentrations were assessed only in those who were not obviously haemolysed $(\mathrm{n}=48)$.

Infant birthweight and gestation were recorded at delivery. To account for variations in birth weight attributable to differences in sex and gestational age, birthweights were converted to their respective centiles, as defined by Gairdner and Pearson. ${ }^{12}$
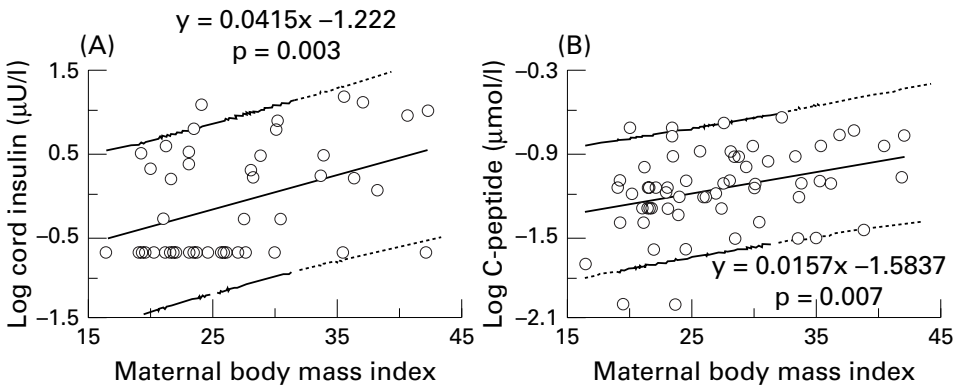

Figure 1 Correlation between early pregnancy BMI and cord insulin (A) and $C$ peptide (B). Straight line indicates the best fit line and the dotted curves show the $90 \%$ confidence interval for individual predictions.

Table 2 Spearman correlation coefficients of cord blood C-peptide and insulin concentrations with individual infant and maternal anthropometric characteristics ( $p$ values in parentheses)

\begin{tabular}{lllll}
\hline & \multicolumn{2}{c}{ Maternal early pregnancy } & \\
\cline { 2 - 4 } & BMI & $F M_{S T M} \dagger$ & $F M_{B I} \neq$ & $\begin{array}{l}\text { Neonatal } \\
\text { birthweight }\end{array}$ \\
\hline Cord C peptide $(\mathrm{n}=60)$ & $0.33(0.008)$ & $0.32(0.01)$ & $0.31(0.01)$ & $0.13(0.32)$ \\
Cord insulin $(\mathrm{n}=48)$ & $0.44(0.002)$ & $0.44(0.002)$ & $0.42(0.003)$ & $0.08(0.57)$ \\
\hline
\end{tabular}

$\dagger$ Fat mass estimated using skinfold measurements; $\ddagger$ Fat mass estimated using bioelectrical impedance.
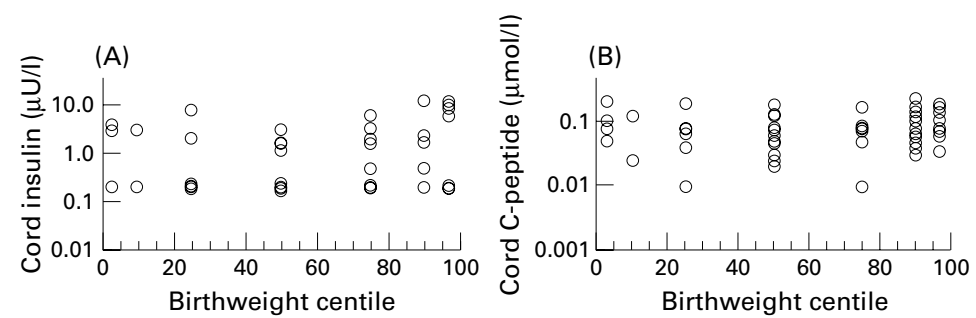

Figure 2 Cord insulin (A) and $C$ peptide (B) concentrations in relation to birthweight centile.
The study was approved by the Ethics Committee of the North Sheffield Hospitals. All 60 volunteers signed consent forms.

The data were analysed using the Statistical Package for Social Sciences (SPSS Version 9). Significance was assessed as a $\mathrm{p}$ value of less than 0.05 . The Spearman correlation coefficient was used to investigate the correlation between infant birthweight and various maternal and fetal variables. Linear regression analysis was undertaken following a log transformation of skewed data.

\section{Results}

The physical characteristics of the subjects are shown in table 1 .

As might be expected, there was a significant correlation between insulin and $\mathrm{C}$ peptide in cord blood; $r=0.41, p=0.002$.

The correlation between maternal early pregnancy $\mathrm{BMI}$ and cord insulin and $\mathrm{C}$ peptide concentrations is shown in figs $1 \mathrm{~A}$ and $\mathrm{B}$. Both cord insulin and $\mathrm{C}$ peptide concentrations were significantly associated with maternal BMI and fat mass (estimated by each method) (table 2).

Infant birthweight was positively correlated with maternal early pregnancy BMI ( $\mathrm{r}=0.43$, $\mathrm{p}=0.007)$ and also with maternal fasting glucose in the third trimester $(r=0.39, \mathrm{p}=0.02)$. A significant correlation was observed between maternal early pregnancy BMI and maternal fasting glucose $(r=0.55, \mathrm{p}=0.0001, \mathrm{n}=25)$. There was no correlation between maternal fasting glucose and cord insulin $(r=0.002$ $\mathrm{p}=0.99, \mathrm{n}=19)$ or $\mathrm{C}$ peptide concentrations $(\mathrm{r}=0.09 \mathrm{p}=0.65, \mathrm{n}=25)$.

There was no significant correlation between infant birthweight and either cord insulin or C peptide concentrations (table 2). Normalisation of birthweight for sex and gestational age differences - that is, conversion to birthweight centiles-did not improve the correlations; $\mathrm{r}=0.20, \mathrm{p}=0.16$ and $\mathrm{r}=0.10$ and $\mathrm{p}=0.42$, respectively (fig 2 ).

\section{Discussion}

As the major substrate for fetal energy metabolism, glucose crosses the placenta via carrier mediated facilitated diffusion. There is no evidence that insulin can cross the placenta from the mother to the fetus, or vice versa, in any significant amount in humans. ${ }^{13}$ Although the molecular weight of $\mathrm{C}$ peptide is about half that of insulin, clinically insignificant placental transfer of this peptide has been reported. ${ }^{14}$

In the model of diabetic pregnancy proposed originally by Pedersen, ${ }^{15}$ it is presumed that excessive maternal glucose crosses the placenta and stimulates insulin production in the fetus. In support of this model, there are studies in humans which show a positive correlation between cord C peptide and/or insulin concentrations and infant birthweight. ${ }^{16}{ }^{17}$ Lin et $a l^{14}$ suggested that persistently low production of insulin in small for gestational age (SGA; birth weight centile $\leqslant 10$ ) and high production of insulin in large for gestational age (LGA; birth weight centile $\geqslant 90$ ) infants might explain the observed differences in intrauterine growth rates. In our study, there was no correlation 
between infant birthweight and cord insulin or C peptide concentrations. The limited number of observations together with high variability among measured cord insulin and C peptide concentrations may have caused this lack of correlation.

We observed a significant correlation between cord insulin and C peptide concentrations, which is similar to the study of Stanley et al. ${ }^{16}$ This is to be expected as they are secreted in equimolar amounts from $\beta$-cells. Lin $e t a l,{ }^{14}$ however, reported no close association between these two variables. They explained that this discrepancy could have been due to the differences in hepatic and peripheral clearance of insulin and $\mathrm{C}$ peptide.

What makes our study unique is the finding of a positive significant correlation between maternal early pregnancy BMI, and in particular maternal fat mass, with both cord insulin and $\mathrm{C}$ peptide concentrations at birth. Maternal fat mass has been associated with maternal basal insulin concentrations in a study of 56 Swedish women by Langhoff-Roos et al..$^{5}$ In a recent study by Silliman and Kretchmer ${ }^{18}$ on the relation between maternal obesity and infant adiposity in 37 subjects, a higher insulin concentration in the obese than the lean mothers was reported at 35-36 weeks of gestation.

The significant correlation between maternal BMI, in particular fat mass, with fetal insulin observed in our study of healthy women, is interesting, but the mechanism behind it needs further investigation with concurrent measurement of maternal glucose and insulin in late pregnancy. It may well be that maternal BMI has an essential role in the increase in maternal glucose via insulin resistance, which could result in higher secretion of insulin in the fetus, eventually producing a bigger infant.

We speculate that reducing maternal BMI, or more precisely, maternal fat mass, might have an impact on the incidence of fetal hyperinsulinaemia and consequent macrosomia. Further research is required to test this assumption.
1 Millner RDG, Hill DJ. Fetal growth control: the role of insulin and related peptides. Clin Endocrinol 1984;21:41533

2 Edwards LE, Dicks WF, Alton IR, Hakanson EY. Pregnancy in the massively obese: course, outcome and obesity prognosis of the infant. Am $\mathcal{f}$ Obstet Gynecol 1978;131:479-83.

3 Gillmer MDG, Persson B. Metabolism during normal and diabetic pregnancy and its effect on neonatal outcome. In: Elliott K, O'Connor M, eds. Ciba Foundation Symposium 63. Pregnancy metabolism, diabetes and the fetus. Amsterdam: Excerpta Medica, 1979: 93-126.

4 Landon MB, Osei K, Platt M, O'dorisio T, Samuels P, Gabbe SG. The differential effects of body fat distribution on insulin and glucose metabolism during pregnancy. $\mathrm{Am}$ f Obstet Gynecol 1994;171:875-84.

5 Langhoff-Roos J, Wibell L, Gebre-Medhin M, Lindmark G. Placental hormones and maternal glucose metabolism: A study of fetal growth in normal pregnancy. $\mathrm{Br} \mathcal{F}$ Obstet Gynaecol 1989;96:320-6.

6 Girandolo RN, Khodiguian N, Mittlemark RA, Wiswell RA. Body composition in pregnancy. In: Mittlemark RA, Wiswell RA, Drinkwater BL, eds. Exercise in Pregnancy. Maryland: Williams \& Wilkins, 1990: 99-108.

7 Lukaski HC, Siders WA, Nielsen EJ, Hall CB. Total body water in pregnancy: assessment by using bioelectrical impedance. Am f Clin Nutr 1994;59:578-85.

8 Durnin JVGA, Rahman MM. The assessment of the amount of fat in the human body from measurements of skinfold thickness. Br f Nutrition 1967;21:681-9.

9 Durnin JVGA, Womersly J. Body fat assessed from total body density and its estimation from skinfold thickness: measurements on 481 men and women aged from 16 to 72 years. Br F Nutrition 1974;32:77-97.

10 Siri WE. The gross composition of the body. In: Tobias CA, Lawrence JH, eds. Advances in Biological and Medical Physics. Vol 4. New York: Academic Press, 1956: 239-80.

11 O'Rahilly S, Burnett MA, Smith RF, Darely JH, Turner RC. Haemolysis affects insulin but not C-peptide immunoassay. Diabetologia 1987;30:394-6.

12 Gairdner D, Pearson J. Growth and development record. Arch Dis Child 1985;60:1202.

13 Kalhan SC, Schwartz R, Adam PAJ. Placental barrier to human insulin $\mathrm{I}^{125}$ in Insulin dependent diabetic mothers. f Clin Endocrinol Metab 1975;40:139.

14 Lin C, Moawad AH, River P, Blix P, Abraham M, Rubenstein AH. Amniotic fluid as an index for intrauterine fetal growth. Am f Obstet Gynecol 1981;139:390-6.

15 Pedersen J. Diabetes and pregnancy: Blood sugar of newborn infants. (PhDThesis). Copenhagen: Danish Science, 1952.

16 Stanley KP, Fraser RB, Milner M, Bruce C. Cord insulin and C-peptide distribution in an unselected population. $\mathrm{Br}$ f Obstet Gynaecol 1992;99:512-8.

17 Godfrey KM, Hales CN, Osmond C, Barker DJP, Taylor KP. Relation of cord plasma concentrations of proinsulin, 32-33 split proinsulin, insulin and C-peptide to placental $32-33$ split proinsulin, insulin and C-peptide to placental
weight and the baby's size and proportions at birth. Early Hum Devel 1996;46,129-40.

18 Silliman K, Kretchmer N. Maternal obesity and body composition of the neonate. Biol Neonate 1995;68:348-93. 